\title{
THE EMPLOYEES MOTIVATION WITHIN AN EVENT ORGANIZING COMPANY DURING COVID-19 PANDEMIC : STUDY OF EVENTX \\ By: \\ Rani Candra Kurniawati,
}

Entrepreneurship/ School of Business and Management, Bandung Institute of Technology

Email : rani_candra@sbm-itb.ac.id

Anggara Wisesa

Email : anggara@sbm-itb.ac.id

\begin{tabular}{l}
\hline Article Info \\
\hline Article History : \\
Received 13 Sept - 2021 \\
Accepted 25 Sept - 2021 \\
Available Online 25 \\
Sept - 2021
\end{tabular}

\begin{abstract}
The entire economy in Indonesia experienced turmoil and decline due to the spread of the Covid-19 virus. Likewise, the event organizer industry also experienced a decline. All event organizer companies are having a hard time. Employee motivation at work is affected by internal and external factors, caused by dispositional factor or internal, such as personality trait, effort, mood, judgment, ability, motive, belief and situational factor or external, such as world's phenomenon, other's people attitude, time of day, task difficulty, and luck. This study analyzes employee motivation affected by dispositional and situational factors and influences employee performance while working in Event Organizer during Covid19 Pandemic. This study uses a qualitative approach with attribution theory and phenomenological method. Researcher conducts semi-structured interviews with three employees of the EventX company. The result of this study is the understanding of the factors that significantly influence the employee motivation of EventX through two approaches, dispositional and situational. The researcher found that there are changes in motivation and affect performance during the Covid-19 pandemic. This study will become a reference to increase motivation levels, especially for event industry amid the Covid-19 situation and enhance employee performance.
\end{abstract}

\section{Keyword : \\ dispositional, situational, employee motivation, event organizer ${ }_{2}$ Covid-19 pandemic}

\section{INTRODUCTION}

The growth of the event industry has been rising rapidly. This growth is majorly driven by the development of best-in-class technology. The meeting, convention, and event planner profession is projected to grow $33 \%$ from 2021-2022, which is much faster than the average growth rate of all occupations $11 \%$.

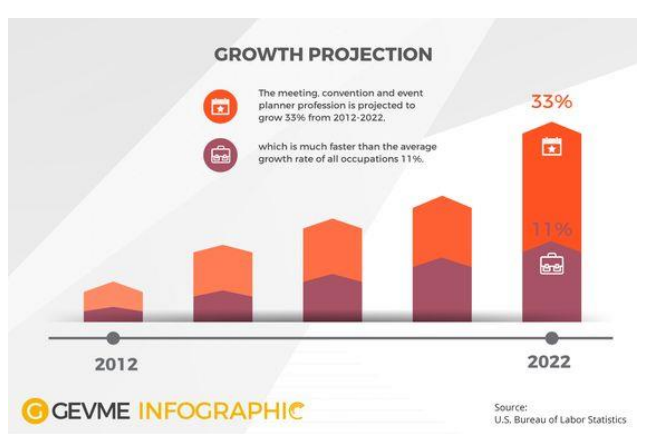


Figure 1 Event Growth Projection Bureau of Labor Statistics)

In 2018, the total purchase of event tickets on loket.com reached more than 10 million tickets. Ticket sales for concert and music festival categories increased 500\%, MICE category ticket sales increased $200 \%$, sports ticket sales increased 225\%, and entertainment attraction category ticket sales increased $250 \%$. Unfortunately, by the end of 2019 , the world faces an unprecedented global health and socio-economic crisis triggered by the COVID-19 pandemic.

Covid-19 is a disease that comes from coronavirus type of infection. Coronaviruses are a family of enveloped RNA viruses (Burrell et al., 2017). The virus emerged firstly in Wuhan, China then spreading globally. The virus became an International concern on 30 January 2020 and declared a pandemic on 11 March 2020.

On 27 June 2021, more than 180 million cases were confirmed worldwide. In Indonesia, as of 26 June 2021, more than 2 million cases were confirmed, followed with more than 50,000 confirmed deaths. During this pandemic phenomenon, several nations had to face social and economic disruption, Indonesia was no exception. Indonesia had an economic downturn, more than what was expected. According to Statistics Center Agency Data (2020), Indonesia's gross domestic product (GDP) shrank in the third quarter 2020, reaching minus 3,49 percent (year on year/yoy). This result happens due to unstable performance in all sector industry circumstances severely caused by Covid-19. Several sectors that have been affected are the tourism industry, financial industry, and property industry and event industry. Event industry has become one of the worst affected sectors caused by large scale offline meeting bans. The Indonesia Professional Organizer Society (IPOS) conducted a survey of 112 Event Organizers spread across 17 provinces. They found that 96 percent of EOs experienced delays or cancellations of events related to the Covid-19 outbreak. Each Event Organize loses potential revenue of between 2.2 billion and 5.6 billion rupiah. If the number of Event Organizers from 7 communities in Indonesia as of May 2018 is 1,218 companies, then the potential loss throughout Indonesia is a minimum of $\mathrm{Rp}$ $2,688,126,000,000$ and a maximum of $\mathrm{Rp}$ 6,939,337,500,000 (Radio, K. B,2020)

COVID-19 has reduced mobilities and productivity of event industry service. Eventually, the event industry was forced to see opportunity behind all the limitations. The employees have to use several ways that can be applied in order to survive in the midst of the Covid-19. Switching offline to online events become one of strategies to pull up the event organizer performance. However, offline activities to online activities have another challenge to be faced. They should provide a lot of stuff through an online approach. Every aspect needs to be developed and keep up with technological developments. The event organizer must use an interactive way to attract customer attention and afterward it can boost company sales. When the event industry could optimize this condition, the event organizer will keep steady and exist in the industry. Unfortunately, an industry can survive if the system of human development is fulfilled. Human resources are the most important thing that can improve the quality of a company. In this case, the event organizer will be able to survive if it has the quality of humans, including in the pandemic situation. Human resource has an important role to support organizations and continue business processes (Gigauri and Iza, 2020).

On the contrary, employees who work away from the office have a big possibility of being distracted. Furthermore, they could feel annoyed if their working place is unconducive. The attitude of each employee will be different, the emotional resilience depends on several factors, e.g. personality, life-experience, environment. Several factors that could impact an employee's performance are distractions from working at home $(21 \%)$, a lack of connection or communication (19\%) and outside of team (14\%) (Magazine, R, 2020)

Many companies implement a working from home for all employees, used on remote technologies to engage with the employees 
(Camilleri, 2021). Maximize the communication through digital media, virtual meetings, and team building activities. Nevertheless, working from home is sometimes disrupted by various jobs that must be done at home (Mustajab, 2020). Then, many people are not unmotivated to work. According to research by management consultancy (Lane4, 2020), 44\% of employees under 35 years old have a lack of motivation and interrupted their work performance since the beginning of the coronavirus outbreak in March 2020, motivation became unclear. Theoretically, motivation has a strong power to achieve people's wants and needs. It drives all human behavior and is the part of initiative, persistence, and intensity of the effort spent by a person to reach a particular result (Anon., 2014).

Motivation is derived from "Motive" which means the needs, wants, and desires of a person (Chaudhary and Sharma, 2012). Motivation is all internal and external power that could make someone take an action, determines someone limits, and do all activities oriented in achieving particular goals (Duică, 2008). According to the study of Honari (2016), motivation generates effort and dynamism that will increase price in the market. Regarding the scale of motivation, motivation will reveal how employees of the organization will be serious in carrying out their duties and responsibilities (Azar and Shafighi, 2013). Employees' motivation is a prerequisite for an organization to achieve business excellence (Tohanean and Toma, 2018). Besides, work motivation is a driving energy to generate enthusiasm to work effectively, cooperate well, and integrate with all the efforts to achieve the satisfaction level (Weiner, 2014). Moreover, motivation evokes people to reach their maximum interaction toward work, working capacity, and work productivity (Ali, Abrar and Haider, 2012).

Work motivation is under the influence of both dispositional and situational factors (Gagné and Deci, 2005). Dispositional attribution is known as internal attribution. It is a way to assume behavioral causes based on internal characteristics, including personality traits, efforts, moods, judgments, abilities, motives, or beliefs (McLeod, 2012). Dispositional attribution concerns to the tendency to ignore the situation of people and judge their behavior based upon what we assume to be their personality. On the flip hand, situational attribution is known as external attribution. It is a concern of behavior that is caused by situations from outside that cannot be controlled, such as world phenomenon, calamity, other people's attitudes, time of day, task difficulty, and luck (McLeod, 2012). Usually, this attribution refers to how people react to the adverse action regarding internal factors then assumes external factors cause their negative performance. Both dispositional and situational will affect employee motivation level. Employee motivation has been broadly defined as "the psychological force to determine the direction of one's behavior in an organization, one's level of effort and one's level of persistence" (Jones and George, 2008). When employees' efforts and persistence meet their expectations then the company will achieve its goals. In the end, only companies that are able to maintain employee motivation will survive in the midst of Covid-19 pandemic.

Regarding these phenomena, the researcher will analyze the internal and external factors that could impact the employee motivation within an event company, called EventX, that was influenced by the Pandemic Covid-19 situation. The researcher will conduct an semi-structured interview with all members in the company, using attribution theory, both dispositional and situational. Furthermore, researcher expect to get the relevant data that will be applied to to improve the employee's performance in the company.

\section{LITERATURE REVIEW}

The world is facing an unprecedented phenomenon, Covid-19. COVID-19 is a disease caused by a new type of coronavirus. 'CO' for corona, 'VI' for virus, and 'D' for disease. Previously, the disease was called '2019 novel coronavirus' or '2019-nCoV. Long after that, every country in the world began to bear the burden. On March 11, the World Health Organization (WHO) declared Covid-19 a pandemic. This awful situation 
affects all aspects, including social, political, economic, and psychological outcomes. From an economic perspective, Indonesia has a large gap between Indonesia's GDP before and during the pandemic. Indonesia's economy plunged into recession last year as it struggled to contain the COVID-19 outbreak (Djumena, E, 2020)

One of the industries most affected by Covid19 is the event industry. The government and public health warn everyone to practice social distancing to prevent the spread of Covid-19. There are many considerations for switching events from offline to online events or even canceling and postponing events in this situation. Fortunately, the opportunities to host online events are growing with advances in technology. However, only companies that can maintain their work adaptability, which will exist.

The virtual meeting format will be one of the best solutions to keep the industry alive. It will encourage event organizers to retain the company. Virtual meetings require extensive planning skills with an understanding and familiarity with online marketing and technology. In addition, the virtual meeting planning team should have members with a sense of digital user interfaces, customer service, and organizing skills, as well as flexibility (Fryatt, et al., 2012). Adapted from Fryatt, et al. (2012) there are eight different technology formats or categories for virtual meetings. There are video conference, conference call, online meeting, webcast, webinar, virtual trade show, 3D virtual world, or hybrid meeting

Table 1 Options for virtual meetings (adapted from Fryatt et al., 2012)

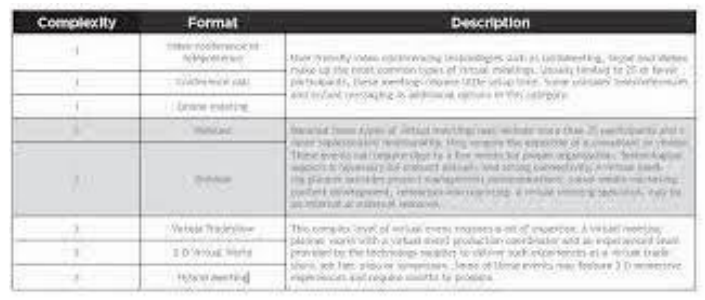

As the GMID Goes Virtual (2020) research shows, there are clear indications that virtual gatherings will lead the event industry. As shown in the figure below, $5.4 \%$ of event planners had held virtual meetings before the pandemic, but $75.7 \%$ of event planners planned to have virtual meetings when the pandemic hit.

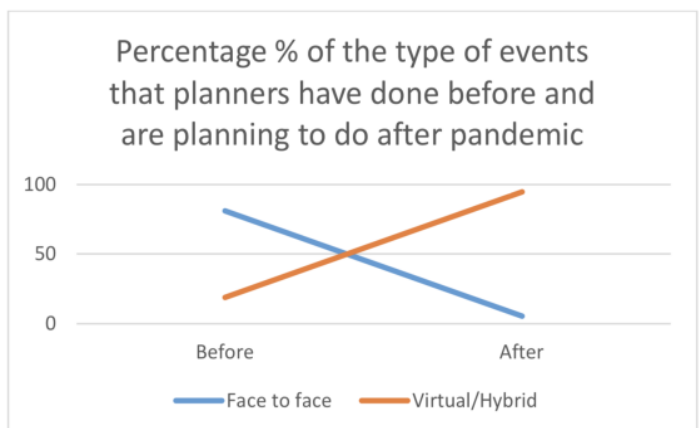

Figure 2 Percentage $\%$ of the type of events before and after pandemic (GMID Goes Virtual, 2020)

Event Organizers as an organization that serves its customer by providing services in the form of event planning, event committees, and other services related to events can use that opportunity, as long as they maximize it.

During the Covid pandemic, based on a survey by Ivendo with Indonesia Professional Organizer Society (IPOS) 2020, 112 Event Organizers spread across 17 provinces, almost half of it came from DKI Jakarta, that 96 percent of Event Organizers experienced delays or cancellations of events due to the Covid-19 pandemic.

Hence, to survive amid Covid, the event organizing company or Event Organizer must carry out various strategies to deal with losses due to Covid -19. According to the continuity survey from Ivendo, most event companies are planning to diversify their products or switch businesses. One of the ways to do product diversification is to take advantage of the online market that continues to grow. At this point, finally, the event industry that wants to survive must be able to adapt and make this Covid-19 phenomenon as a challenge, not an obstacle, to be able to innovate with products or online services.

To do an online system, adaptation must be made quickly and precisely. All aspects of the company must work together to take 
advantage of this opportunity. However, this adjustment will create a big gap for the employees, where they must change all their habits at work. The level of motivation in this case greatly affects the adjustment of employees. Satisfied and motivated employees are an invisible part of a successful and competitive enterprise (Vydrova, 2018). However, motivation is a feeling hidden inside a person that cannot be forced (Bin Saeedet al., 2019). Furthermore, motivation factors are crucial for employees (Fratricova \& Kirchmayer, 2018).

Unfortunately, Covid-19 is currently affecting employee motivation. This is also felt by employees at one of the Event Industry companies, EventX. EventX is an entrepreneurial e-ticketing platform, providing events: seminars, webinars, and workshops with one main issue, entrepreneurship. We are classified into two approaches, B2B and B2C. During Covid pandemic, the motivation of all employees has changed. Furthermore, this will affect the stability and sustainability of the company.

Employee motivation is caused by two approaches, dispositional and situational factors. Dispositional factors are internal causes, and situational factors or external factors are associated with other people or the environment.

A dispositional factor is a way to assume behavioral causes based on internal characteristics, including personality traits, efforts, moods, judgments, abilities, motives, or beliefs (McLeod, 2012). Situational factor is a concern of behavior caused by situations from outside that cannot be controlled, such as world phenomenon, calamity, other people's attitudes, time of day, task difficulty, and luck (McLeod, 2012). Continually, employee motivation will drive employees to reach their employee performance. Regarding motivation at work, it relates to building initiation and concern for individual goal performance (Larsson et al., 2018).

Every company has a responsibility to improve the performance of its employees because of the importance of achieving optimal goals (Nassazi, 2013). Performance can be influenced by several factors: individual personality, values instilled in it, attitudes, and personal competencies, which are a mixture of how they perceive things and their motivations (M'Mbui, 2011). Furthermore, according to research, whether motivation affects people's performance at work, there is a relationship between motivation and performance (Deci \& Gagne, 2005). Organizational leaders can still motivate employees by providing various ways by relying on the creativity and flexibility of employees in carrying out their obligations as employees (Humala, 2017).

From all these findings, this study aims to analyze the motivation of employees affected from dispositional and situational factors while working in event organizers in the midst of Covid-19. Since the goal of the research is to examine the participants' experience according to their personal views, a qualitative research study was chosen. A qualitative study will explore and describe a central, primarily social, phenomenon (Wallen \& Fraenkel, 2001), using attribution theory (dispositional and situational factors) and phenomenological approach.

\section{METHODOLOGY}

Phenomenology is theoretically concerned about a phenomenon, such as people's experience. Phenomenology is a study between experience or consciousness, based on people's first point of view. Phenomenology forms into various types of experience, notably, individual perception, emotion, desire, memory. The main structure of phenomenology is intentionality. Furthermore, the purpose of phenomenology examines people's feelings and uniqueness in the way they lived. Phenomenology studies conscious experience, analyzing the types of intentional forms, meanings, dynamics, and enabling conditions (Smith, 2018). Patton (2002) contends that phenomenology as an approach to answer the following question: "What is the meaning, structure and essence of the lived experience of this phenomenon for this person or group of people". The subjective view of experience portrayed by phenomenology is a crucial "part of any full 
understanding of the nature of knowledge" (Moran, 2000).

According to classical Husserlian phenomenology, people's experience directly only comes from certain factors, such as thoughts, ideas, images. This activity formed the meaning of those experiences. Phenomenology develops a complex account of temporal awareness, spatial awareness, attention, awareness of one's experience selfawareness, the self in different roles, embodied action, purpose or intention in action, awareness of other persons, linguistic activity, social interaction, and everyday activity in our surrounding life-world.

In phenomenology, the researcher will enter into someone's world to find out their experience. This study will answer questions related to a person's process in carrying out their life. Researchers will collect answers and analyze the participants' experiences. How participants know their experiences will be the primary data in analysis and interpretation. A key component of phenomenology is the description of people's experiences (Moustakas, 1994, as cited in Creswell, 2007). This method would be ideal because researchers seek to understand, describe, and interpret human behavior and the meanings humans make from their experiences." (Carpenter, 2013, p. 117)

\section{RESULT AND DISCUSSION}

4.1Transcendental-Phenomenological

\section{Reduction}

Researchers conducted this study by directly examining the problems faced by informants in one company called EventX. The researcher analyzes the causes and effects of dispositional or internal factors and situational or external factors in each individual in influencing employee motivation, especially in the Covid-19 condition they are facing. Researchers find some similarities in individual behavior, both from the internal and external factors that result in changes in motivation at work. This analysis is carried out transparently and takes an in-depth look at the phenomena being felt by individuals. The researcher, in this case, positions herself in neutrality without giving direction or encouragement to the source in answering a question. The results of the analysis obtained are pure and original from the statements of the informants.

\subsection{Horizonalization}

The horizontalization stage was carried out starting with obtaining verbatim transcripts of interviews and reading every transcript to get a feel of the content as a whole (Giorgi \& Giorgi, 2003) and emotional tone (Angrosino, 2003).

Researchers completed the horizontalization process by compiling interview transcripts which were then used for analysis in a study. Researchers can see answers that lead to the informant's experience and eliminate statements that are not related with the topic. 4.3 Textural Analysis

In this study, researchers will analyze the influence of each factor on employee motivation which is felt directly by the informants. The informant's statement will be strong evidence that the factors mentioned have a relationship with employee motivation.

In the current business environment, especially in the Covid-19 situation, several factors perceived by informants will change and affect the level of employee motivation. Therefore, researchers will review these variables, which may affect employee motivation changes.

\subsection{Structural Analysis}

In this study, researchers will analyze how each factor influences employee motivation during Pandemi Covid. Researchers will categorize in four categories, such as dispositional factor and employee motivation, situational factor and employee motivation, employee motivation factor, and employee performance and employee motivation.

\subsubsection{Dispositional Factor and Employee Motivation}

The dispositional factor is known as internal attribution. It is a way to assume behavioral causes based on internal characteristics, including personality traits, efforts, moods, judgments, abilities, motives, or beliefs. 
Regarding researcher analysis involving three informants, as an employee in EventX, Josua as Chief Executive Officer, Izzani as Chief Operating Officer, and Rehan as Chief Technology Officer, researchers find several effects between dispositional factor and employee motivation. Furthermore, Josua thinks that personality traits will affect him to have work motivation in the company,

“...with personality, I can be able to recognize my strengths and my weaknesses. Further, it supports me to be more focused and be able to work, including in EventX...It influences my motivation to do all my tasks in EventX. During Covid, I could say if the effect of personality comes stronger." (Josua)

Along with two other informants, they explain if personality traits are the important factor to drive their motivation. Besides, personality traits relate to individual effort. As Chief Technology Officer Rehan said, that effort is one thing that affects a person's level of responsibility. Izzani also conveyed as Chief Operating Officer that effort will appear when we have responsibility,

"...effort becomes a responsibility. If the opportunity is big, I am always motivated to perform." (Rehan)

“...Usually it will appear when I have more responsibility. I believe "We have to get what we fight for" that drives me to do better and higher my motivation..." (Izzani)

During Covid situation, informants feel that their effort quantity changes slightly compared to the situation before Covid. Izzani said,

“...But unluckily I will be less focused with this Covid pandemic. This situation affects my working not just for the company but also tasks in my daily life..." (Izzani)

"...Sometimes, including in this pandemic, when I do not think I do not have any job to be done, I will be less motivated..." (Rehan)

This situation also affects the informant's judgment, where Josua thinks that good communication between EventX can affect him in his work. Unluckily, when this pandemic occurs, all EventX members cannot meet. Therefore, the EventX team had problems communicating, which resulted in the delay of several decisions. Josua also thinks that a great benefit will bring him to high spirits as if EventX could allocate some of its revenue for members' salaries.

“...Event $X$ cannot give us a salary. The revenue will be used for company saving and development expenses. So, I cannot deny that this work sometimes does not become my priority." (Josua)

Then, all informants think that they can boost their motivation if they have a judgment and ability, continually with challenges that they could get related to their job.

“...I will be more motivated if I get a bigger challenge on it and judgment also will lead me to make good decisions for the company..." (Izzani)

“...If my abilities match with my job, then it motivates me to work harder. If it is suitable but not optimal and still below the average, It makes me work and study harder in my contribution..." (Josua)

From that challenge, it supports informants to do their job harder. Furthermore, Izzani, as Chief Operating Officer, said that motives could drive her to learn new things,

“...when I feel less excited about a job, but no one can do it except me, then it will encourage me to do it even though I am not very interested in it at first."

Rehan and Josua conveyed different opinions regarding the motives. Rehan, as Chief Technology Officer, said if his motives in 
doing a productive job in EventX is not high, because Event $X$ cannot give him a salary,

"I am a very money-oriented person. The more the motive, the faster the project is delivered regarding priorities. So, during work with EventX, sometimes I am not maximizing my task because EventX does not give a salary or reward for each of us."

Following Josua's statement. However, Josua, as Chief Executive Officer, says the possibility of EventX on further,

“...I think because right now, Event X still cannot give employees salaries, but I will not be concerned about it. I want to make EventX bigger, so it influences me to have the motivation and work to my ability well."

Continually with Izzani that explains if we have a belief, so it will support us to do our task,

“...to be motivated, I must believe in myself. Belief is very important for me. It helps me to have a mindset, If I believe so I can." (Izzani)

4.4.2 Situational Factor and Employee Motivation

The situational factor is known as an external factor. It is a concern of behavior caused by situations from outside that cannot be controlled, such as world phenomenon, calamity, other people's attitudes, time of day, task difficulty, and luck. Situational factors as an external condition that can affect people's behavior or performance. In this step, research will analyze how situational factors influence employee motivation, gathered from three informants, Josua as an employee in EventX, Josua as Chief Executive Officer, Izzani as Chief Operating Officer, and Rehan as Chief Technology Officer.

In the Covid-19 condition, EventX has their struggle. Regarding this world phenomenon, many strategies of the company have changed. All members switch all the activities from offline to online. Josua, as
Chief Executive Officer, explains that during this condition, his motivation gets lower.

“...This affects my motivation to work because there are fewer people I meet in person, and that makes me less enthusiastic, whereas at work we need to meet other people to have better communication. Although it has adapted to the virtual, this activity requires more energy because the adaptation process requires fast time...."

Along with Izzani's opinion as Chief Operating Officer, she thinks that Covid situation makes her aware of her mood swings. Sometimes she cannot control it,

"The Covid-19 situation increased my mood swing. I have to control my mood not to affect my work motivation."

Continually with Rehan as Chief Technology Officer, he said that many things have changed. There is the difference before, and while Covid think sometimes he does not feel the value of togetherness and feels this motivation is decreasing $50 \%$,

“...before Covid, we can meet and discuss work-things face to face with fast follow-up, but during Covid, follow-up is delayed. Furthermore, I do not get the value of togetherness... my work motivation is currently down to $50 \%$. I am not as productive as I used to be. The pandemic very impacted my quality of work, especially my energy."

However, all informants see the opportunity behind the condition. Josua continually explain if there is a chance for EventX to grow bigger,

“...because all activities happen online, this becomes a very profitable opportunity for our business (EventX) to carry out business activities more easily. Webinars are made easier because we use an online platform and can be attended by anyone and anywhere" (Josua) 
Furthermore, the existence of EventX can be stable if all members can nurture their motivation. All informants can leave their bored-level with spending more time for metime.

Along with all their statements, if they have their strategy to boost their motivation on work. Rehan said that he has a strong coping mechanism, Izzani said that she has their way to boost her spirit, and Josua said he could explore new things,

“...my coping mechanism is good. When I feel tired and need time, I usually play games, listen to music, watch movies, and rest. That is the fastest way to increase my performance..." (Rehan)

“...To boost my spirit, usually I do me-time on the weekend, such as exercising and watching movies" (Izzani)

“...I have higher self-awareness and explore new things such as managing finances, learning to mix music, learning investment and trading, and learning digital marketing..." (Josua)

It is important to have our own me-time because it will boost our energy and increase our motivation. Like what Rehan said in the following sentences,

"But, I forced myself to have motivation. When I am doing a project or anything, I think I have to finish all things that have been started. I will think about goals and values that I will get when I succeed..." (Rehan)

Sometimes other people's attitudes will affect our motivation. Izzani, as Chief Operating Officer, said that someone attitude could affect her mood, and during Covid, she becomes more sensitive,

“...Recently, since the COVID-19 pandemic, I have become more sensitive. Maybe it influenced me to experience mood swings multiple times and its effect on work. Sometimes I feel unmotivated to give my best at work."

Continually Josua, as Chief Executive Officer, thinks that other people's attitude toward him can influence him to work better,

"However, when someone criticizes me, I will use it as motivation and an opportunity to improve my work performance. I think that situation is warrantable."

However, Josue explains that inside the company, no one member has a bad attitude towards others. The different opinion given by Rehan, as Chief Technology Officer. He said that if he got criticism or bad attitude by others, he does not take it to heart, but do introspection,

"...I do not care what people say, then I do introspection, I do not take it to heart..."

Continually, the other factor that will boost their motivation is how well they manage their time. Reyan explain if time management is very important,

"Time management is important. I will prefer to prioritize all my tasks..." (Rehan)

Both Josua and Izzzani also agree that time management is important. They have a strategy to optimize their daily routine.

Furthermore, sometimes task difficulty can trigger someone's capability. Josua, as Chief Executive Officer, said that he would have higher motivation if the task difficulty is more serious,

"The higher the difficulty level of the task, the higher my motivation to do so. It requires more effort, so my motivation will be higher..."

Then, sometimes there is one factor that can lead us to success, it is luck. Josua thinks that 
luck factor will be our opportunity to support us to get success,

“....Sometimes, there are jobs that are completed because of luck. Then we do not need more effort to complete them. For example, before Covid, EventX did not run optimally, but during Covid, we can hold many events, is it called luck? I think so..." (Josua)

Different opinions with Rehan that explain if everything can be achieved with our effort or dedication. He prefers to not believe in luck but effort,

"I am not very concerned about this factor at work. I will be more confident in my ability to do a task, as well as during Covid. “

Lastly, every member has their different most decisive factor that can lead us to increase their motivation. Still, to develop EventX, especially amid Pandemic, every member has to support and help each other if there is any task difficulty in the process and prioritize in their daily routine.

\subsubsection{Employee Motivation Factors}

The study of motivation is concerned with the internal factors that drive a person to act and external factors as inducements to act. Three aspects influenced by motivation are goals, incentives, and desires. Besides, motivation is a person's inner strength to provide energy to achieve personal goals and move all the potential possessed.

In this step, researchers will analyze all aspects that will influence informant motivation. Josua is Chief Executive Officer, Izzani, as Chief Operating Officer, and Rehan, as Chief Technology Officer.

Regarding the interview data, all informants said that 'Goal' is the most significant impact that can influence their motivation and continually give an outstanding performance. Izzani, as Chief Operating Officer, said that goals would give her spirit,
"...Goals will give me the spirit to do my job, I have a reason to be motivated to achieve these goals..."

Continually with Rehan statement, as Chief Technology Officer, he wants to improve the EventX website,

“...Goals affect my motivation and performance at work. For EventX, as a technology employee, I want to improve the quality of the website..."

Additionally, Rehan explain if this covid condition makes him to can not maximizer the progress,

"....but during Covid, sometimes the finish schedule is delayed."

Goals become a factor that could improve employee motivation along with incentives. Rehan said if he wants to earn money. Therefore, sometimes he does not optimize his work on EventX because EventX can not afford salary for all employees,

“...But, EventX is still in process, when Event $X$ gets income, we have to use it to develop the brand, not for a salary. Because of that, sometimes, I am not optimal in doing my task..."

According to Covid situation, Izzani, as Chief Operating Officer, explain that her motivation is getting lower,

“...But during Covid, my motivation is a little bit low because I have limited communication with the team."

However, she has 'wants' and 'needs' that could drive or make her still on the track,

“...'want' is directly affecting my work performance. For example, when I have to coordinate along with Rehan to develop our website. We can work at it for quite a long time...need is essential. It triggers me to work hard to achieve it. I can be energized to do a task in EventX 
because it is affecting my academic assessment." (Izzani)

Furthermore, Josua, as Chief Executive Officer, said if, amid Covid, he just wants to make EventX condition stable,

“...Despite Covid, Ijust wanna make EventX stable, for this year, we never hold events yet. We prefer to build a website and other things...I want to make one big event at least. It will challenge us to be more productive in EventX and pull up the brand."

Following with his statement about 'need', which is essential as well as 'wants.'

"If my work motivation and work performance is high, then I will get my needs. I become persistent when I have something to achieve..." (Josua)

Along with Rehan's opinion, he agrees if 'need' can boost his motivation. From all these findings, researchers think all members have their opinion regarding all factors, but they say that earning a salary can increase their motivation.

4.4.4 Employee Performance Factor and Employee Motivation

Employee performance is the results from a job, which is achieved by someone in an organization under his responsibility to achieve organizational goals. Performance is expected to be relevant to the employee's job and employee role. In this section, the researcher will analyze how employee performance factors can be formed through the influence of employee motivation through interviews with Josua as Chief Executive Officer, Izzani as Chief Operating Officer, and Rehan as Chief Technology Officer.

From all the findings, there is a correlation between employee performance and employee motivation. According to Josua, as Chief Executive Officer, he said that individual motivation could drive him to get work performance,
“...Individual motivation such as ambition and goals create my high work performance...Having high work performance can fulfill my needs and wants. According to that, motivation is useful, and there is a certain satisfaction when achieving my goals..."

Following Rehan opinion, as Chief Technology Officer, that work performance will be achieved when a company have team appreciation

“...Work performance also can be achieved through team appreciation, including in this Covid situation. If I join a meeting and someone asks my opinion, it matters because it means I am needed..."

Furthermore, Izzani, as Chief Operating Officer, thinks that goals as a factor that can influence her to have high work performance.

"...if I have goals to create new things, then my work performance will also increase. I think the important factor in boosting my motivation is when I have goals and dreams. Also, the environment around me is positive...."

However, due to Covid, she said that her motivation is not stable,

“....During Covid, I felt my motivation was unstable. Sometimes this situation makes me a bit moody and affects my motivation. Usually, I get distracted by activities that my family does. It makes me unfocused to do my task at home." (Izzani)

Despite the fact that EventX cannot work well, because regarding Josua as Chief Executive Officer opinion, EventX will grow more significant if we can get funding to help us improve the brand and to increase the total customer, 
"EventX canot perform well because we have a limited budget to develop some stuff." (Josua)

Continually with his explanation, EventX can grow better if the company could get funding that will be used to develop EventX products and services. EventX has worked together as one team to meet the company's goal,

"So we have to find a way to get funding. Nowadays, we can try our luck by joining a startup pitch competition that offers funding as a winner prize. So, although Covid, it has not stopped me from making a move and utilizing our opportunity, as long as we work together as one team, not individually. If I can nurture these goals and give effort, it also will boost my work performance." (Josua)

Thus, it seems that if EventX team can nurture their goals, effort, and appreciation, their work performance will be higher.

\section{CONCLUSION}

In this study, the researcher found that employee motivation can be affected by the Covid-19 pandemic. Based on the analysis, employees of EventX company felt the differences in motivation before and during a pandemic. According to attribution theory, the researcher analyzed the employee motivation level through two factors: dispositional and situational factor. Dispositional refers to the internal factor and situational refers to the external factor. Through a semi-structured interview with an employee in EventX, Josua as Chief Executive Officer, Izzani as Chief Operating Officer, and Rehan as Chief Technology Officer, the researcher found if this phenomenon, Covid-19 pandemic, could bring them to a change of motivation.

Employees stated if both dispositional and situational factors are affecting their motivation during work in the Covid-19 pandemic. Employees cannot work productively and effectively. However, employees feel dispositional factor have a bigger impact on their motivation than situational factor. Individual factors are employee challenges that must be maintained to create positivity into motivation, continually influencing work performance. Employees could trigger themselves to build up their spirit through having a challenging job that they never have done before or spending more time for 'me-time.

Regarding the development of EventX, based on the interview, the employee could optimize their strategy to find some funding that will be used to develop their website and be an encouragement for all employees. The company could be sustained by acquiring customers and having various collaborations with event organizers by maximizing the opportunity to do online approach during Covid-19 pandemic. Then revenue in the company will automatically grow. In the end, the company can achieve bigger revenue and allocate them into several aspects, including salary for employees, which is expected to improve employee work enthusiasm.

\section{REFERENCES}

Mustajab D, 2020. Working from home phenomenon as an effort to prevent Covid-19 attacks and its impacts on work productivity. Vol 4, No 1

Camilleri, M.A., 2021. Evaluating service quality and performance of higher education institutions: A systematic review and a post COVID-19 outlook. Int. J. Qual. Serv. Sci. Marinescu, P., Toma, S.-G. and Constantin, I., 2016. Talent management in the age of globalization. Man-ager, 24, pp. 180-184.

Toma, S.-G. and Marinescu, P., 2018. Business excellence models: a comparison. Proceedings of the Inter-national Conference on Business Excellence, 12(1), May 2018, pp. 966-974.

Chaudhary, N \& Sharma, B. (2012). Impact of Employee Motivation on Performance (Productivity) In Private Organization: International Journal of Business Trends and Technology, volume2, Issue 4.

Honari, H. (2006). Investigation of motivation and productivity of Iran's physical education organisation in Tehran, Harakat: Abstract Book on Nine's National Congress on Tehran, Iran, (27, 45-54). 
Azar, M \& Shafighi, A. (2013). The Effect of Work Motivation on Employees' Job Performance:International Journal of Academic Research in Business and Social Sciences, Vol. 3, No. 9 ISSN: 2222-6990.

Ali, A. Abrar, M. \& Haider J. (2012). Impact of Motivation on the working performance of employees- A case study of Pakistan: Global Advanced Research Journal of Management and Business Studies Vol. 1(4), pp. 126-13

Deci E, \& Gagne M,. (2005). Selfdetermination theory and work motivation. Journal of Organizational Behavior , Jun2005, Vol. 26 Issue 4, 331-362

Humala, I. 2017. Typology On Leadership Toward Creativity In Virtual Work. Interdisciplinary Journal of Information, Knowledge, and Management, 12, 209-243

Erol, Y. \& Kanbur, E. (2014). Entrepreneurial characteristics of Turkey's top 100 industrial enterprises according to their mission and vision statements. Business and Economics Research Journal, 5(3), 149165.

Roos, W. and Van Eeden, R. (2008), "The relationship between employee motivation, job satisfaction and corporate culture", SA Journal of Industrial Psychology, Vol. 34 No. 1, pp. 54-63.

Mustajab, D., Bauw, A., Rasyid, A., Irawan, A., Akbar, M. A., \& Hamid, M. A. (2020). Working from Home Phenomenon as an Effort to Prevent COVID-19 Attacks and Its Impacts on Work Productivity. The International Journal of Applied Business (TIJAB),4(1),

13-21.

http://dx.doi.org/10.20473/tija

b.V4.I1.2020.13- 21 